Article

\title{
Implementing Integrated Water Resources Management in the Ebro River Basin: From Theory to Facts
}

\section{Jorge Bielsa ${ }^{1, \dagger}$ and Ignacio Cazcarro ${ }^{2, \dagger}, *$}

1 University of Zaragoza, Department of Economic Analysis, Faculty of Economics and Business, 50005 Zaragoza, Spain; E-Mail: jbielsa@unizar.es

2 Basque Centre for Climate Change (BC3), 48008 Bilbao, Spain

$\dagger$ These authors contributed equally to this work.

* Author to whom correspondence should be addressed; E-Mail: ignacio.cazcarro@bc3research.org; Tel.: +34-944-014-690; Fax: +34-944-054-787.

Academic Editors: Ram Babu Singh and Xiangzheng Deng

Received: 19 August 2014 / Accepted: 24 December 2014 / Published: 31 December 2014

\begin{abstract}
In this article, we analyze how successful the implementation of Integrated Water Resource Management (IWRM) in the Ebro river catchment (in Spain) has been. Our main aim is to show some gaps between theory and practice. This implies analyzing the political dimensions of governance and their change and reflecting on the interface between governance and technical knowledge about water. We highlight problems, such as the lack of institutional coordination, blind spots in technical information and path dependences. Actual water management has led to plans for further irrigation even though water availability is, and is expected to continue, shrinking due to climate change and other local factors. To overcome these mismatches, we propose further synchronization, innovative ways of public participation and knowledge sharing between institutions and researchers. As a showcase, we portray a practical real example of a desirable institutional arrangement in one sub-catchment.
\end{abstract}

Keywords: IWRM; sustainability; Ebro river catchment; Matarraña sub-catchment 


\section{Introduction}

Nowadays, there is a consensus on the big gap that still exists between theory and practice when it comes to Integrated Water Resources Management (IWRM) [1,2]. Although some studies have found elements of IWRM in some cases (see this Special Issue [3]), the key question is not if this gap exists but whether it is decreasing fast enough [1,4-7]. The Global Water Partnership [8-10] created tools designed to support the development and application of IWRM based on three categories: (a) Enabling Environment; (b) Management Instruments; and (c) Institutional Roles. IWRM principles include: planning for all sources of water; addressing water quantity, quality and ecosystem needs; incorporating principles of efficiency, equity and public participation; and having a multidisciplinary and multiagent approach and sharing of information [7,11]. The implementation process has been described as an iterative spiral of four phases: (1) recognizing and identifying; (2) conceptualizing; (3) coordinating and detailed planning; and (4) implementing, monitoring and evaluating [12].

According to [13], during the last two decades and at the global level, almost $80 \%$ of countries have made changes in their water laws. Nevertheless, a new law does not mean that its application and real consequences appear automatically. There are a lot of traditions, inertias, common practices and hysteresis that can easily obstruct the best policy. So, it is necessary to develop a shared understanding of the meaning of the best policies and a specific way of quantifying their results. Due to these difficulties, practical guides have been published, e.g., [14], while other examples of implementation, e.g., in Latin America, can be found in [15].

The Ebro river basin has had a specific water agency for water management since 1926, the Ebro Hydrographic Confederation (EHC), which could be considered as one of the preconditions for a truly integrated management. Though the geographical scale from which water has been governed seems to be adequate, there are also other overlapping institutions and agents that make the actual management more complex. At the continental level, the European Union (EU) enacted a new legal framework in 2000, known as Water Framework Directive (WFD). This directive started the move towards more participative and ecosystemic approaches at river basin level, i.e., it is the entrance gate of IWRM into the former legal and institutional framework. Since all the EU members had to adapt their legal framework to WFD tenets, it was supposed that this directive would change water management in Spain in the direction of integrated management.

Nevertheless, looking at the horizontal and vertical interrelation with other governance structures [16], we find some contradictions. The organizational structures, the economic incentives and participative dynamics can result in deficiencies in the application of the principles of IWRM even if they are well acknowledged in the basin plans blueprints or in the law that they are supposed to respect.

In this article, we look at these mismatches and try to analyze the level of success of the implementation of IWRM in the Ebro River Catchment. Our aim is to highlight problems, such as the lack of institutional coordination and the difficulties of bringing recent knowledge on Economy, Hydrology and related sciences into daily water resources management. Regarding institutional grounds, we emphasize some inconsistencies between the conventional rigid top-down water policies and the new social and environmental water demands. We want to show, by means of a case study, that an innovative bottom-up institutional arrangement can overcome inertias and conflicts. Following [17], our prior is that there is a wide range of possibilities between the "market" and the "state" dichotomy. 
Regarding the technical-institutional interface, we highlight the question of expected mismatches of actual water supply and demand under climate change projections and the quantities and qualities considered in current water planning. The main issue is that, following [18], adaptive water management constitutes an effective mitigation measure to climate change. According to [19,20], the impact of reduced water availability in the year 2050 could amount to a welfare loss of $\$ 10,559$ million for Spain as a whole. Due to the acceleration of these changes and the continuous flow of new papers and studies, no institution or agency can afford to be disconnected from new insights in natural science research. We will show some clear-cut examples in which such a disconnection is evident.

The remainder of the paper is organized as follows. Section 2 provides the background for IWRM in the Ebro basin looking at the geographical area, climate and institutions. Section 3 presents the main contradictions between actual and theoretical water management. We also provide considerations regarding the allocation rules for traditional versus new water uses and their implications on the current institutional framework. Section 4 describes what some researchers and practitioners (e.g., [21]) have suggested might be one of the few cases of the application of, or at least of great improvement towards IWRM in a sub basin, the Matarraña river. This case study aims to be an illustration of the ideas raised in Section 3. Conclusions and future endeavors are presented in Section 5.

\section{Background for Integrated Water Resources Management in the Ebro Basin}

The Ebro catchment drains an area of about $85,000 \mathrm{~km}^{2}$ in northeastern Spain which climate pattern-considered both inter-annually and intra-annually-follows the typical Mediterranean regime. This means high variances in yearly time series and an average flow roughly halving in summer. Water is also unevenly distributed in space, with much more rainfall at the head of the tributaries than at its mouth in the Mediterranean Sea at Tortosa. One important fact, which is becoming more and more conspicuous, is the clear downwards-sloping trend of its stream-flow at this point. Indeed, this flow has almost halved since the middle of the past century, from around $15 \mathrm{~km}^{3}$ to the current $8.5 \mathrm{~km}^{3}$. Human activities can only explain half of this marked and worrying trend [22].

Since 1926, a basin agency (Ebro Hydrographical Confederation) carried out water management and planning for the whole catchment. Political decentralization during the last three decades, though, has seen the appearance of a network of Autonomous Communities, which overlaps with the former natural basin framework. The Spanish Constitution established that water had to be managed at State level for the interregional basins (those shared by two or more Autonomous Communities, as is the case of the Ebro basin-green ovals in Figure 1) whereas, for intraregional basins (those framed only in one Autonomous Community), water is managed through the creation of regional water agencies. River basin hydrographical confederations are supposed to be the executive arm of the central administration, through the Directorate General for Water (DG Water), located in the Ministry of Agriculture, Food and Environment (MAGRAMA). Completing the picture, the Autonomous Communities (with growing competencies) have their own water agencies although local Governments have no tradition in planning or management at river basin level. Summing up, recent history has created a complex network of institutions whose harmony is far from easy [23]. On top of this institutional scheme, at least in theory, is the European Union by way of the above-mentioned WFD. 


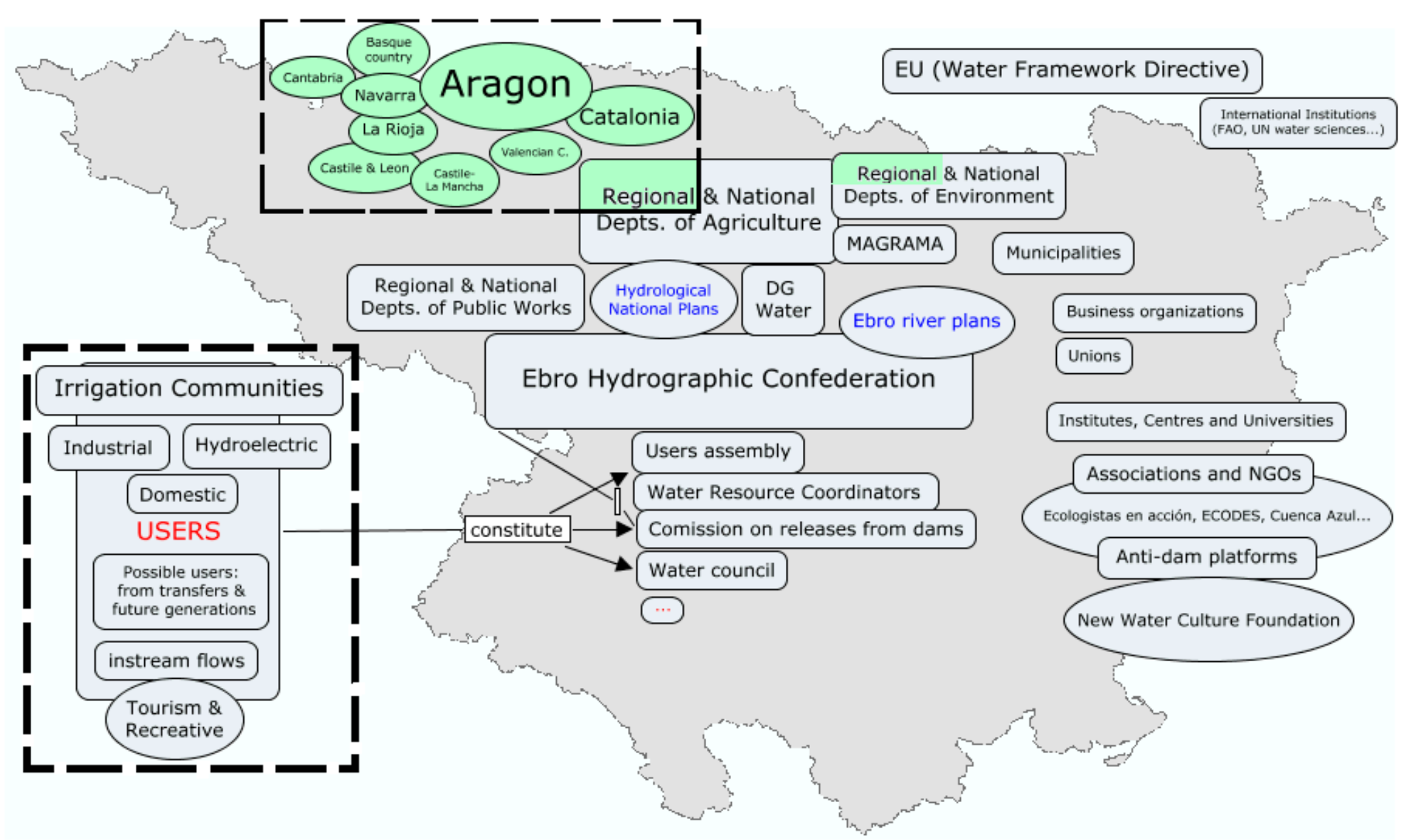

Figure 1. Conceptual map of the agents and interrelationships in the Ebro catchment. (Rectangles represent the described entities constituting the institutional framework of the Ebro basin. The left dotted box contains the type of water users. The upper dotted box, green ovals represent the regions involved in the management of the catchment; the rest of the ovals are examples of adjacent entities (rectangles), those with blue text being examples of the main water plans developed for the basin; Source: Own elaboration.) 
In addition to these main agent-institutions, there are several organizations and stakeholders affected (see Figure 1). The size of each item reflects its relative representation in the (Ebro River Basin) Water Council of the EHC, which is the institution that makes and implements the important decisions and plans in a top-down manner.

The Water Framework Directive, although not fully matching IWRM, (see [24]), the Spanish water management law (through article 14 [25]) and the Ebro Hydrographical Confederation plans [26,27]) have statements, guidelines and objectives of integrated water resources management. The Ebro Basin water plan [26] states in its introduction that "In order to increasing the availability of the resource, protecting its quality, saving and rationalizing its uses in harmony with the environment and other natural resources, water planning will be guided by criteria of sustainability in water use through integrated and long-term protection of water resources, prevention of deterioration of water status, etc.". Appendix 5 of the document, explicitly mentions the Global Water Partnership and the Second Report of the United Nations Development on Water Resources.

Furthermore, in the Ebro River Basin, a few experiences consistent with the approaches introduced by the Water Framework Directive (WFD) existed although not planned under an IWRM at river basin level, and a few others have been created afterwards [28].

The question that we want to deal with in the next section is whether all the statements above are more than merely a case of empty words and whether the experiences are coherent with IWRM.

\section{Three Categories of Challenges for an Effective Application of IWRM in the Ebro Basin}

In this section we present the key challenges in the three categories of the Global Water Partnership [8-10] tools to support the development and application of IWRM in the Ebro basin. These three categories have to do with (i) the capabilities of accomplishing an ecosystemic (multidisciplinary, accounting for new scientific challenges) approach; with (ii) management instruments that enable moving from partial to total cost recovery; and with (iii) achieving high levels of participation and institutional coordination between the agents/stakeholders involved. Our hypothesis is that only by advancing in these three dimensions will an integrated water management be accomplished. The empirical evidence and theoretical base come from the list of papers we compile for each aspect we want to highlight.

\subsection{Ecosystemic Approach: Water Supply, Demand and Climate Change}

Below, we present, analyze and discuss studies and data on the supply and demand of water, mainly collected from several databases and Geographical Information Systems of the Spanish Ministry of Environment, the EHC and an integration of other works' projections on future water demand [29-36]. The quantity and quality of water resources are interrelated aspects, and in this way have been considered in the basic representation of Figure 2. There we plot the yearly run-off (for simplicity only the information of those points with more than $1 \mathrm{~km}^{3}$ ), which is located essentially along the central Ebro River running from the northwest to southeast. We also show water demand by water type, storage capacity and land cover of the Ebro catchment. The main purpose of the figure is to give an insight of the importance of the irrigated land surface (in orange). This irrigated land, much more than urban requirements (in red); explain the water demand increases in the basin. On the supply side, the 
growing natural vegetation (in green), especially where the rivers get most of their water, explain a part of the above-mentioned decrease in the yearly run-off at the river mouth in Tortosa. Agricultural water demand is very high in terms of green water (precipitation that does not form part of surface water flows but is directly or indirectly returned to the atmosphere, shown by the green bar) and even higher if we consider grey water (grey bars). These bar graphics, which are provided by Water Resource Coordinators (juntas de explotación in Spanish), show how blue water (blue bars between the grey and green ones) and domestic water consumption (pink) are much smaller.

Let us explain the previous general view in more detail. The annual flow from the mouth of the Ebro River into the sea at Tortosa has noticeably decreased from the levels of the mid twentieth century. These reductions imply an increase in salinity, a decrease in nutrients and sediments, and threats to flora, fauna and ecosystems, noticeably endangering the sustainability of the Delta [37,38]. Recent studies on water supply in the Ebro catchment have made new forecasts about water availability under different future climate change scenarios. Chavez-Jimenez et al. [39] characterizes the behavior and sensitivity of water resources in relevant Spanish basins under the impact of climate change. [40] identified potential water scarcity across the Ebro catchment whilst [41] points out that if irrigated areas increase by $50 \%$ - as the new Ebro Basin Plan [42] puts forward - there is not enough water in the basin to meet such a demand. According to [30], water resources could decrease by $25 \%-35 \%$ at the 2050 horizon in the Ebro valley and by $15 \%-20 \%$ in Pyrenean sub-catchments (in the lowest part of the range of forecasts). Finally, [34] estimates a reduction in contributions of 5\%-15\% and explores several measures to help reduce the basin's vulnerability to climate change.

Furthermore, we know from [43] that reductions in the availability of water that cannot be explained either from the demand side (water uses) or from the supply side (runoff) can be attributed to the growth of natural vegetation as an effect of rural abandonment during the second half of the past century. These findings have been confirmed and estimated in [44-47]. In [22] the authors investigate the economic consequences of such a change in terms of agricultural losses. López-Moreno et al. [33] consider both the climate change and re-vegetation, forecasting a striking fall of $30 \%$ in $2020-2050$ runoff in the case of the Aragon river sub-catchment. With the same consideration, in [48] the declining annual flows of the central Pyrenees are found between 19\% and 32\%, depending on the studied watershed. Finally, García-Garizábal et al. [49] make a climatic characterization of a historical series (1971-2000) and its future projections (2011-2099) for an Irrigation District located in the Middle Ebro valley. They find an increase in reference evapotranspiration and a decrease in precipitation, producing a twofold effect both on agriculture demands and in water supply.

Despite all the above, the current draft of the Ebro Basin Hydrological Plan [26] states that, when the evaluations of the climate scenario prepared by the Ministry of the Environment are not available, a rigid percentage $(5 \%)$ of the global reduction of natural contributions must be applied. The plan seems to have ignored all the extensive above-mentioned literature for which that reduction for 2050 is expected to be in the range $15 \%-35 \%$. 


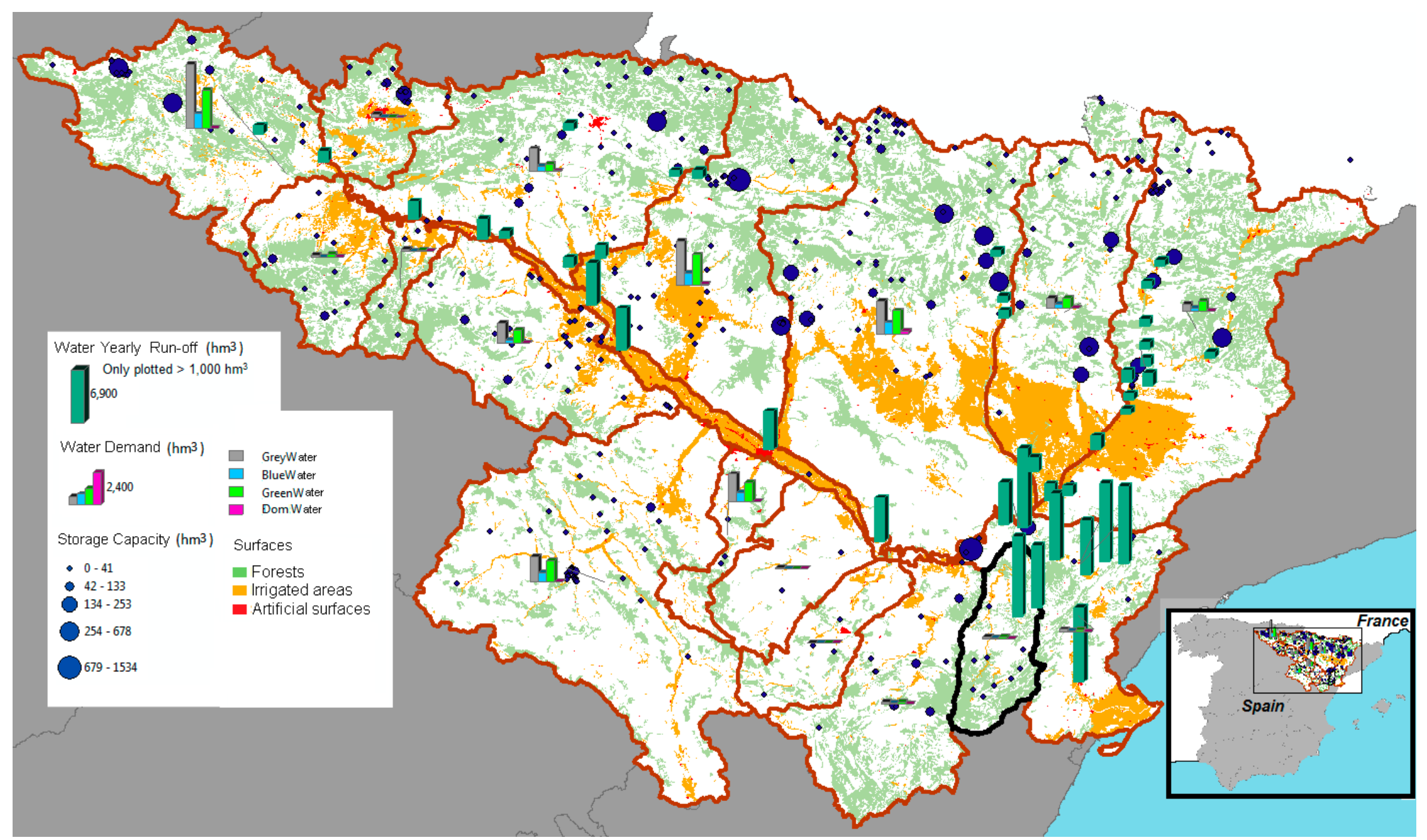

Figure 2. Yearly run-off (only plotted $>1 \mathrm{~km}^{3}$ ), water demand by water type, storage capacity and land cover of the Ebro catchment. (Source: Own elaboration based on $[29,30]$.) 


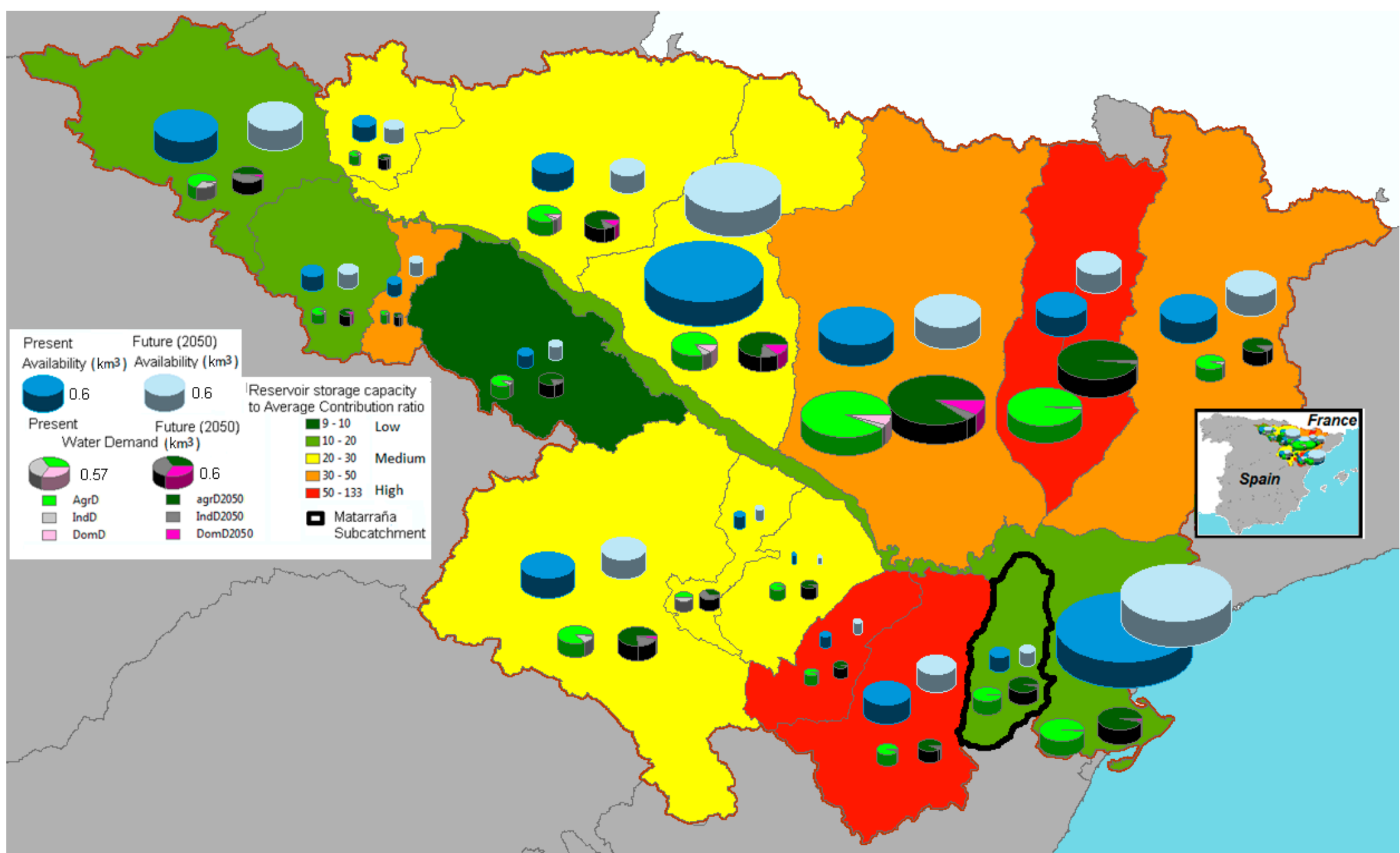

Figure 3. Reservoir storage capacity to Average Contribution; present and future availability and demands. (Source: Own elaboration based on $[29,31,32,35,36]$.) 
Figure 3 summarizes this contradiction in a geographically detailed manner. The three color pies show the current and future water withdrawals (climate change scenarios for 2050 drawn from the above-mentioned literature), distinguishing agricultural (green), industrial (grey) and domestic (pink) demands, those of 2050 being in darker colors, while the reservoir capacity to natural streamflow (1980-2005) ratio is shown by the colors of the Water Resource Coordinators regions. Present potential availability is approximated (with two assumptions. For the current potential, we assume 10\% of environmental reserve as $[32,35,36]$. On the other hand, we assess the future potential is expected to suffer a global reduction of about $25 \%$ (depending on the regions, based on $[30,48]$ ) due to the expected combined effect of climate change and revegetation. Despite high storage capacity in certain areas, once considered the potential water availability for the whole Ebro catchment, the demands are not easy to meet, particularly in summer. The black contour highlights the southeastern sub-catchment of the Matarraña River, further discussed in Section 4.

\subsection{Management Instruments: From Partial to Total Cost Recovery}

Water management basically implies the design and implementation of allocation rules. As we have shown in the previous subsection, it is not expected to be water enough for all the competing users in a future "normal" hydrological year in the Ebro Basin at current water tariffs. In this case, conflicts between traditional users and new ones is not the exception but the rule. These traditional users of available water (i.e., offstream agricultural users and instream hydropower generation) have had the lead in the past. But new needs and agents have been appearing, in general of instream flows uses, such as tourism and recreational activities. The same can be said about the necessary environmental flow regimes, fish propagation and protection, and wildlife habitat.

The system has survived because the necessary investments were paid mainly by the State, the regional governments or the European Commission [50]. For many researchers, the principle of the total cost recovery is one of the main preconditions for a true IWRM. Indeed, this is one of the keystones of the WFD [51]. This European legal body clearly states that water costs should involve counting not only the infrastructure construction, maintenance and management costs but also the environmental and the so called resource costs (opportunity cost), that is to say, the welfare loss due to the best alternative use.

The European Commission has recently launched a warning call [52] on the poor incentives for water consumption reduction of current tariffs. Furthermore, there is abundant literature pointing out that a change should be made on the water pricing front. We can cite here the contributions of $[53,54]$. Among the solutions to meet water supply and demand, some authors have proposed new calculations for water pricing based on its local scarcity (resource opportunity costs) as in the recent papers of $[55,56]$.

Some of the above considerations have been taken into account in the preambles and in the "literary" section of the draft of the Ebro Basin Hydrological Plan. But few of them appear when it comes to the establishment of actual water tariffs. In general terms, water tariffs remain a means of recovering part of the financial costs associated with water provision, whilst there is no trace of pollution externalities or scarcity costs in the calculations, whether theoretical or practical, of the final water tariff. In other words, the current legislation and Ebro river plans on tariffs, more precisely, the water 
control tariff and the water utilization tariff (see [25,27,57-60] for their description and summary), do not include the concepts of environmental costs and resource costs that the WFD requires to be included, estimated and recovered [51].

\subsection{Institutional Roles: Participation and Institutional Coordination}

It is clear that participation and institutional coordination are becoming more common all over the world. An updated review of this issue can be found in [61]. At the same time, there is some empirical evidence that IWRM processes promote the necessary institutional changes to improve the water allocation system. Some researchers highlight the great challenge of getting diverse water users across entire watersheds to agree on new policies and institutional structures [62]. Collective action with multiple and diverse actors increase transaction costs, i.e., of negotiation, bargaining and searching for solutions, which are known to hinder institutional change [63-66].

This situation is complicated even more by the fact that it is not just the water sector that is involved in political and management choices, but also the sectors of agriculture, industry, energy and the environment [1]. Well-established interests may fight to avoid altering their historic paths and preferences for water allocation [67-69]. In the Ebro catchment, there are many of these path dependences that create frictions or slow down the speed of the changes.

According to [70] integrated water resources management must be achieved gradually. In the case of Spain, facing water management challenges has entailed, in some sub-basins, relatively innovative solutions, which, together with the current economic crisis, might be seen as a window of political opportunity for institutional change [54,71,72].

However, the current draft of the Hydrological Plan of the Ebro Basin [26] does not seem to incorporate these innovative solutions. There is a formal participative process in the preamble and some room for different stakeholders to express their points of view, but the plan is elaborated and, more importantly, decided, through the centralized institutional framework described in Section 2, that is, by the majorities and power shares of the current Water Council. This top-down procedure is not conducive to incorporating the different aspects described above.

For the Ebro basin as a whole, in order to have a real integrated management, it is necessary to bring together all the existing scientific knowledge, to introduce economic instruments, which account for the scarcity value and externalities, and to facilitate negotiation processes through new institutional designs. In other words, to count on the real participation of new agents and researchers both as providers of critical information and as new players in the bargaining process. Only then, can the long-term plans achieve the continuity and credibility that [73], amongst others, calls for. But this could well be just another big statement without any real content. In order to avoid this, we are going to describe the elements and the process carried out, almost spontaneously, in a sub-catchment of the Ebro basin as an example. The focus on this small sub-catchment is intended to serve as a positive example of what we recognize as a relevant IWRM process and outcome. 


\section{An Example of an Approach to IWRM: The Matarraña Sub-Catchment}

Following the excellent report of [21], we can obtain a clear cut picture of the multiple-layer case of the Matarraña river basin agreement signed in 2000. First we describe the subject background and the facts and then the lessons we can draw to illustrate some of the above mentioned ideas.

\subsection{Hydrological, Socioeconomic and Institutional Background}

The Matarraña is a southeastern tributary of the Ebro River. Its sub-catchment could be considered a small-scale reproduction of a typical Mediterranean basin, but with slightly milder intra-annual climate contrasts. However, its inter-annual climate patterns are highly irregular, with very frequent drought periods. The Matarraña can be seen as a smaller version of the bigger Ebro River Basin, as we are going to show.

As in the Ebro basin as a whole, the higher Matarraña sub-catchment does not have severe problems of water scarcity. Consequently, several water control and distribution works have been built to secure water for the middle and lower river stretches: a reservoir, two diversion tunnels, and a pumping facility. Furthermore, due to the good quality of the water and the attractive landscape and cultural heritage, rural tourism has been a flourishing source of economic development since the early nineties. As a result, local people have increasingly rejected these projects, which have always been promoted by the EHC. Irrigated land - which accounts for the bulk of water consumption - is concentrated in the middle and lower river basins. The concentration of most of the irrigation-dependent lands in the middle river basin has had the effect of making its users dominant in the institutions representing them. From an environmental perspective, it is worth noting that the Matarraña is considered to be one of the Mediterranean rivers with the most outstanding biodiversity. It is probably one of the best conserved in the Iberian Peninsula, and needs to be maintained by way of the allocation of minimum environmental water flows.

With respect to the institutional framework and its particular interfaces and interactions in this case, the list of water managers and stakeholders include all the institutions mentioned in Section 2 for the whole basin as well as two that are specific to this area, namely, the Central Union of Irrigation Communities (IC) and the social-environmental Association for the Defence of the Matarraña (PLADEMA).

The situation at the end of the 1990s, before the Matarraña Agreement was signed, was that in years of drought, the river did not have enough water to meet urban freshwater, environmental streamflow, livestock and irrigation demands. In the 1998-1999 water year, the drought reached such a level that it triggered a change due to the accumulation of past tensions and contradictions, that is, the weak integration of agents and goals in water management. Let us now turn to the story of the negotiations, which took place, their results in the Agreement and the lessons we can draw in terms of integrated water resources management.

\subsection{The Matarraña Agreement: The Facts}

The beginning of the summer of 1998 found the low basin in a critical situation. As a consequence, the demand for a large water project in the middle and lower basin strengthened. Many representatives 
of water users (irrigation farmers and some municipalities) supported the construction of the Torre del Compte dam. This contrasted with the point of view defended by PLADEMA, which considered the costs of this project would be too high both economically (project costs and consequences for the tourism industry) and environmentally.

At that moment, the only existing infrastructure for water regulation held less than one third of its capacity and the pumping project was idle because the river had no extra flow. The municipalities of the lower basin, given that they were the last users to receive water from the reservoir, withdrew their support for the Torre del Compte project and expressed a preference for elevating water from the river Ebro. Between 1995 and 1999, the EHC built and started to operate another water pumping solution (from the Matarraña to the Pena reservoir). The EHC also proposed other water provision alternatives, such as the construction of lateral pools.

In summer 1999, water scarcity problems continued and were even harder than in previous years. The persistence of the drought and its harmful effects drove the basin actors to meet and to try to reach an agreement between as many relevant actors as possible. It is worth noting that an NGO, "Ecología y Desarrollo" (Ecology and Development, ECODES) played a key role in organizing, studying, informing, encouraging and coordinating the users in advance of the meetings, leading to an understanding and recognition of each others' views and needs. The commission was then constituted by representatives of the regional government (Diputación General de Aragón, DGA), PLADEMA, the Municipalities of the basin, the IC (farmers), and experts from the universities of Zaragoza and Barcelona. In the meeting, a consensus was reached and the option of two lateral pools was chosen as the best solution. But this bottom-up agreement did not mean anything without the acceptance of the EHC, it being the sole legal authority able to give it due enforcement.

Meanwhile, the Ministry of the Environment announced it would finance some wells in the headwaters of the rivers. The municipalities of the higher basin soon announced their opposition to the project, alleging that it was going to be placed in one of the most attractive natural areas of the basin and that it would also have negative effects on surface waters. Finally, the EHC rejected the project because both the high basin municipalities and the regional government (DGA) opposed it.

Finally, at the beginning of 2000, the municipalities, the IC, PLADEMA and the Ecology and Development Foundation (representing the environmental and conservationist interests and promoting the meeting) reached an agreement that was also supported by the regional government and the $\mathrm{ECH}$. In this way, an example of bottom-up integrated water agreement was already signed and assumed by all the involved stakeholders. Table 1 summarizes the main contents of the agreement:

Table 1. Matarraña water agreement content: means and conditions.

\begin{tabular}{|c|c|}
\hline Means & $\begin{array}{c}\text { Construction of Two Lateral Pools Fed with Water Diverted from } \\
\text { the Matarraña and Ebro Rivers }\end{array}$ \\
\hline Condition 1: & Environmental preservation of the whole Matarraña river bed \\
\hline Condition 2: & $\begin{array}{l}\text { All parts reject the wells in the higher basin } \\
\text { (and anywhere else if there is no social agreement) }\end{array}$ \\
\hline Condition 3: & $\begin{array}{l}\text { Possibility of a definite solution for water regulation within the basin } \\
\text { (Torre del Compte dam) remains open. }\end{array}$ \\
\hline
\end{tabular}

Source: Own elaboration. 
The importance of this agreement is not in the selection of the most suitable infrastructure to manage water, but in that it manifested a change from a disconnected to a more integrated institutional design. The agreement was signed by practically all the actors operating at the river basin level and, for the first time, a shared perception and definition of the problem was expressed: the river is the axis of the Matarraña river basin and its preservation is a condition to guarantee social and economic development. No doubt, the severe drought sparked this transition, but climate conditions alone cannot explain how this real change in terms of integration of visions was achieved. In fact, drought periods are a characteristic of Mediterranean climate and there had been similar situations in the past. This process had more to do with uniting a comprehensive network of actors in order to understand each other's problems and views and with the reports from both the involved and independent agents.

\subsection{A Final Comparison of the Theory and Facts of IWRM in the Ebro and Matarraña River Basins}

The literature on "bottom up" and "scaling up" management and on "demonstration projects" is extremely abundant. We can find it referring to general problems (e.g., recently [74-79]) and to the specific case of water management (e.g., [80-87]). As indicated above, many studies on IWRM have also stressed mismatches between theory and practice (e.g., [88-91]) and how a particular case could represent innovative insights or "good IWRM practices". Table 2 is a short guide to the theories and facts with respect to the three categories of IWRM: (a) Enabling Environment, which we extend to Ecosystemic approach; (b) Management Instruments; and (c) Institutional Roles. It is not intended to be a comprehensive compendium of the contents of all the above papers; neither does it reflect all the applications of these theories (facts). To sum up, we use the case of the Matarraña sub catchment agreement as a natural experiment to identify lessons that can be scaled up and applied to larger basins.

Regarding to the Ecosystemic approach (a), we find that the Matarraña experience allowed the participants to learn from the state of the art literature about the environmental and social costs as well as benefits of infrastructure works and about long-term water supply and demand in Mediterranean ecosystems. All this was possible because of the participation of a wide range of independent experts who attended the meetings and carried out complementary activities, such as preparing technical reports warning of the damage that the construction of water infrastructures could cause in the Matarraña basin. They also identified the need to modernise irrigation systems and they organised workshops and conferences. As explained in the first subsection of Section 3, this ecosystemic approach is not taken into consideration by the new Ebro Basin Plan.

With respect to Management instruments (b), it is evident that this experience does not provide any specific lesson. None of the concrete agreements question the way in which water is allocated or propose an alternative way of managing the competing demands. This is the biggest blind spot and the weakest point of the agreement. The same could be said about the management instruments at the Ebro catchment level, as we have shown with the compiled literature about the subject in Section 3.2. The slightest change in water allocation or pricing needs a real change in the balance of power around water management. There has not yet been any change in this front from the initial framework showed in Section 2, so the water allocation system has not changed either. 
Table 2. The three categories of Integrated Water Resources Management principles and their theoretical and practical treatment at different levels.

\begin{tabular}{|c|c|c|c|c|}
\hline & & $\begin{array}{c}\text { (a) Ecosystemic Approach and } \\
\text { Scientific Knowledge Consideration }\end{array}$ & $\begin{array}{l}\text { (b) Management Instruments: Economic } \\
\text { (Supply-Demand) Allocation and Pricing }\end{array}$ & $\begin{array}{l}\text { (c) Institutional Roles: Interaction } \\
\text { among All Actors and Negotiation }\end{array}$ \\
\hline \multirow{3}{*}{$\begin{array}{l}\text { Theory/ } \\
\text { law/ } \\
\text { plans }\end{array}$} & IWRM * & $\begin{array}{l}\text { Integration of various scientific, } \\
\text { disciplines, including natural and } \\
\text { social scientific knowledge }\end{array}$ & $\begin{array}{l}\text { Demand oriented. It stresses the economic } \\
\text { instruments and negotiation }\end{array}$ & $\begin{array}{c}\text { Pro-active citizen participation. Institutions } \\
\text { collaborating (allowing bottom-up experiences), } \\
\text { identifying conditions for collective action for the } \\
\text { management of common pool resources. }\end{array}$ \\
\hline & WFD & $\begin{array}{l}\text { Ecosystemic and participative. } \\
\text { Introducing River basin districts }\end{array}$ & $\begin{array}{l}\text { Economic analysis of water uses, total costs } \\
\text { recovery, incentive pricing and } \\
\text { cost-effectiveness criteria. }\end{array}$ & $\begin{array}{l}\text { Pro-active citizen participation. } \\
\text { Active involvement of interest groups and } \\
\text { the public at large in river basin management }\end{array}$ \\
\hline & $\begin{array}{l}\text { Ebro River } \\
\text { Basin Plan }\end{array}$ & $\begin{array}{l}\text { Subject to supra-basin directives } \\
\text { (State and WFD) in the preambles. }\end{array}$ & $\begin{array}{l}\text { Subject to supra-basin directives } \\
\text { (State and WFD) in the preambles. }\end{array}$ & $\begin{array}{l}\text { Subject to supra-basin directives } \\
\text { (State and WFD) in the preambles. }\end{array}$ \\
\hline \multirow{2}{*}{ Facts } & $\begin{array}{c}\text { Ebro River } \\
\text { Basin }\end{array}$ & $\begin{array}{l}\text { Only supply side approach. } \\
\text { No integration with current scientific } \\
\text { knowledge in social or } \\
\text { natural sciences. }\end{array}$ & $\begin{array}{l}\text { Traditional administrative tariffs } \\
\text { and fees and water quotas. }\end{array}$ & $\begin{array}{l}\text { Decisions taken by the River Basin Authority } \\
\text { (strongly biased towards traditional users) } \\
\text { after consultations. Emphasis on supply side } \\
\text { instruments and top-down approach. }\end{array}$ \\
\hline & $\begin{array}{l}\text { Matarraña } \\
\text { SubBasin }\end{array}$ & $\begin{array}{l}\text { From } 2000 \text { onwards, with real } \\
\text { participation and wide agreements. } \\
\text { Scientific experts' considerations } \\
\text { were taken into account. }\end{array}$ & Should be considered. & $\begin{array}{l}\text { Commission with representatives of the EHC, } \\
\text { regional government, municipalities, PLADEMA, } \\
\text { the IC and ECODES. Bottom-up approach. }\end{array}$ \\
\hline
\end{tabular}

* Note: There are more, but we have highlighted only some of the most common aspects and international principles that have been agreed in major conferences and summarized

in works, such as $[24,92]$ 
The most important lessons can be drawn from the third point Institutional roles (c). The common denominator of all the stakeholders involved in the Matarraña case was their perception of the rigid and outsider nature of the supply side solutions proposed by the EHC. As [93] put it, they found it "questionable to rely on the ready-made solutions or the technical fixes". Later on, the common denominator shifted to the preservation of the river as the keystone of social and economic development of the area. In this way, the change of values and interests initially located in the higher river catchment extended to the rest of the basin. Following [94], we should ask ourselves to what extent this agreement contributed to the achievement of more effective, equitable and sustainable outcomes through the participant's learning, adaption and increased trust. Since the EHC and regional government attended and accepted the final document, its content became part of the water management rules. The main lesson we can draw from the agreement is that the bottom-up procedure allowed a real integration of means and goals. In comparison, the Ebro river catchment lacks a comprehensive representation of the different agents involved in the discussions and planning. Examples of the practical and concrete aspects found useful in bridging the gaps are: (1) In the case of leading institutions of water plans, such as, in this case, the EHC, the necessity of recognizing, encouraging and listening to local demands and meetings, formally and informally; (2) In the case of organizations, such as Non-Governmental Organizations (NGOs), research institutes, universities, etc., taking the role of organizing, studying, informing, encouraging and coordinating the meetings of users for their mutual understanding and recognition; (3) In the case of the meeting agents, formally and informally informing the governing and planning body, such as the EHC of those demands and meetings; (4) In the meetings, allocating time to understand each agent's views; (5) Allocating time to attempting to define a common view and general goal for the river, which ensures its future and that of the agents dependent on it.

The analogous Ebro sub-catchment governing jurisdictions probably could be the ones benefiting the most from these insights given that the types of agents involved are essentially the same, and the challenges are often similar as well. Thinking in the lessons for scaling-up or following a similar process for the whole Ebro basin, it is worth noting that Figure 1 represented almost the same structure of agents identified in the Matarraña case. The main difference might be that the (Ebro River Basin) Water Council is still an advice body and needs to gain in importance for the integration of problem definitions and actors in the policy network.

The initial hypothesis was that only by improving on the three mentioned dimensions, can we guarantee a true IWRM. These observable progresses in two of the three categories in the Matarraña case prove that a bottom-up procedure was more adequate. The fact that, even in years of drought, no more conflicts among users have appeared after the agreement supports this assertion. There is a good case for extending these results across the rest of the sub-catchments of the Ebro basin.

Furthermore, the agreement has proven its soundness and consistency in later years. A renewed agreement was signed by the same actors in 2005 and issued as "Dictamen del Matarraña" [95]. This document essentially contains a renewal of the former agreement with more legal and technical specifications about how water was to be managed and the legal basis under which the Matarraña River was to be protected. The document also contains a preliminary approach to management issues by way of water efficiency in irrigation and water transport. The renewed agreement, like the previous arrangement of 2000, did not include any proposal of change as to how water is allocated or priced. 
Finally, as a way of following and monitoring the real application of the new relations framework, the actors decided in 2009 to create a "River Contract", an institutional figure based on the French water management tradition (see [96]). This figure has no legal authority but constitutes, using the words of [97], a real advance in stakeholder involvement in river basin management and planning.

\section{Conclusions}

In this paper, we have tried to show that there is still a large gap between the theory and practice of IWRM in the case of the Ebro basin. It is relatively easy to incorporate good sounding words from speeches and statements of intent into law, but it is costly to do so developing facts and concrete plans.

The long history of top-down state-planned water management in the Ebro basin has allowed the settlement of certain inertia and resistance to change from the interest groups that managed the water for much of the last century. At the same time, new institutions and new needs that overlap with the above have emerged and try to participate in water management. Overall, this resistance to change can be summarized in the difficulties encountered in moving from supply side solutions with rigid administrative allocation of concessions to management models of demand with more flexibility and negotiation.

In this article, we highlight the effects of some of these path dependencies that create frictions or impede the changes from occurring faster in the Ebro catchment. We show that, to avoid this, it is necessary to accept and recognize the existing scientific knowledge in water management plans, to introduce economic instruments which account for the scarcity value and externalities, and to facilitate negotiation processes through new institutional designs.

As a corollary of all the above considerations, one could claim that, to date and in the Ebro basin as a whole, there is no fully integrated management in practice. The integration of new insights from different agents and researchers on the projected changes of availability and demand in a climatic and social change scenarios would result in a more consistent and coherent long-term plan.

To illustrate the necessary transition mentioned above, we describe in some detail the negotiations that took place in a small sub-catchment at the end of the twentieth century. Extreme climate conditions forced a group of stakeholders of the Matarraña sub-catchment to meet and consider with all their consequences the different needs and socioeconomic goals of this specific area. The final agreement, but more importantly, the process that led to it, shows the way to a real integration.

We draw two lessons from the case study. First, we conclude that no integrated management solution can be obtained from just an engineering supply side perspective. General knowledge of all the natural and social sciences must be taken into account. Second, that the move from old top-down to new bottom-up management involves institutional change which in turn, necessarily implies a reduction of the bargaining power of certain deep-rooted groups of interest. Neither of these two conclusions are new and they have been extensively described and dealt with in theory in scientific papers in social sciences (e.g., [98-102]). However, we think that the practical and concrete aspects developed in this article could be useful in resolving these flaws in practice. We have identified the roles for leading institutions of water plans in recognizing, encouraging and listening to local demands; roles for NGOs, research institutes and universities, those of organizing, studying, informing, encouraging and coordinating meetings; and roles for users in the need of understand and recognize 
other agent's views. As a common goal, we believe that efforts to find common views and objectives for the river and to ensure its future and that of the agents that depend on it have been very positive in the showcase.

\section{Acknowledgments}

We like to thank the editors and the anonymous reviewers for their very useful and constructive comments and suggestions that greatly contributed to improving the final version of the article. Of course, all remaining errors are solely our own responsibility. The authors acknowledge that the research was partially financially supported by the projects of the Spanish Ministry ECO2010-14 929 and ECO2013-41353-P. Ignacio Cazcarro also acknowledges his previous project (Award Number 1115025) of Directorate for Social, Behavioral \& Economic Sciences of the National Science Foundation (United States): Impacts of Global Change Scenarios on Ecosystem Services from the World's Rivers. Dynamics of Coupled Natural and Human Systems $(\mathrm{CNH})$ and the present support he receives at the $\mathrm{BC} 3$ Basque Center for Climate Change, supported by the DECCMA project.

\section{Author Contributions}

Both authors contributed to the analysis and writing of the paper. Both authors have read and approved the final manuscript.

\section{Conflicts of Interest}

The authors declare no conflict of interest.

\section{References}

1. Biswas, A.K. Integrated Water Resources Management: Is It Working? Int. J. Water Resour. Dev. 2008, 24, 5-22.

2. Hooper, B. River Basin Organization Performance Indicators: Application to the Delaware River Basin Commission. Water Policy 2010, 12, 461-478.

3. Teisman, G.; Edelenbos, J. Editorial Note on Special Issue on Integrated Water Resources Management. Available online: http://essential.metapress.com/content/y25223112x725771/ (accessed on 24 December 2014).

4. AWRA Position Statement: Call for a National Water Vision and Strategy. Available online: http://www.awra.org/policy/policy-statements--water-vision.html (accessed on 24 December 2014).

5. Bourget, P.G. Integrated Water Resources Management Curriculum in the United States: Results of a Recent Survey. J. Contemp. Water Res. Educ. 2006, 135, 107-114.

6. Najjar, K.F.; Collier, C.R. Integrated Water Resources Management: Bringing It All Together. Water Resour. IMPACT 2011, 13, 3-8.

7. National Report: Responding to National Water Resources Challenges, Building Strong Collaborative Relationships for a Sustainable Water Resources Future. Available online: http://www.rivernetwork.org/resource-library/national-report-responding-national-water-resourceschallenges-building-strong-coll (accessed on 24 December 2014). 
8. GWP. Rationale for IWRM and the Toolbox. Available online: http://www.gwp.org/en/TheChallenge/IWRM-Resources/ (accessed on 29 December 2014).

9. Global Water Partnership (GWP). Main Features of the Toolbox. Available online: http://www.gwp.org/ToolBox/ (accessed on 29 December 2014).

10. Global Water Partnership (GWP). Toolbox: List of Tools. Available online: http://www.gwp.org/ToolBox/ (accessed on 29 December 2014).

11. GWP. Catalyzing Change: A Handbook for Developing Integrated Water Resources Management (IWRM) and Water Efficiency Strategies. Available online: http://www.un.org/esa/sustdev/csd/ csd13/documents/bground_5.pdf (accessed on 24 December 2014).

12. IWRM Guidelines at River Basin Level-Part 2-1: The Guidelines for IWRM Coordination. Available online: http://unesdoc.unesco.org/images/0018/001864/186418e.pdf (accessed on 24 December 2014).

13. The UN-Water Report Status Report on the Application of Integrated Approaches to Water Resources Management. Available online: http://www.un.org/waterforlifedecade/pdf/un_water_ status_report_2012.pdf (accessed on 24 December 2014).

14. A Handbook for Integrated Water Resources Management in Basins. Available online: http://www.inbo-news.org/IMG/pdf/GWP-INBOHandbookForIWRMinBasins.pdf (accessed on 24 December 2014).

15. García, L.E. Integrated Water Resources Management: A 'Small' Step for Conceptualists, a Giant Step for Practitioners. Int. J. Water Resour. Dev. 2008, 24, 23-36.

16. Howitt, R. Scale. In A Companion to Political Geography; Wiley-Blackwell: Malden, MA, USA, 2003; pp. 138-157.

17. Ostrom, E. Beyond markets and states: Polycentric governance of complex economic systems. Am. Econ. Rev. 2010, 100, 641-672.

18. Georgakakos, A.P.; Yao, H.; Kistenmacher, M.; Georgakakos, K.P.; Graham, N.E.; Cheng, F.Y.; Spencer, C.; Shamir, E. Value of adaptive water resources management in Northern California under climatic variability and change: Reservoir management. J. Hydrol. 2012, 412-413, 34-46.

19. Ludwig, R.; Roson, R.; Zografos, C.; Kallis, G. Towards an inter-disciplinary research agenda on climate change, water and security in southern Europe and neighboring countries. Environ. Sci. Policy 2011, 14, 794-803.

20. Roson, R.; Sartori, M. Water Scarcity and Virtual Water Trade in the Mediterranean. Available online: http://ecomod.net/system/files/vwtm2.pdf (accessed on 24 December 2014).

21. Subirats, J.; Font, N.; Costejà, M. Case Study 1: Matarraña River Basin; Universidad Autonoma de Barcelona: Barcelona, Spain, 2002; p. 68.

22. Bielsa, J.; Cazcarro, I.; Sancho, Y. Integration of hydrological and economic approaches to water and land management in Mediterranean climates: An initial case study in agriculture. Span. J. Agric. Res. 2011, 9, 1076-1088.

23. Sánchez-Martínez, M.-T.; Salas-Velasco, M.; Rodríguez-Ferrero, N. Who Manages Spain's Water Resources? The Political and Administrative Division of Water Management. Int. J. Water Resour. Dev. 2012, 28, 27-42.

24. Rahaman, M.M.; Varis, O.; Kajander, T. EU Water Framework Directive vs. Integrated Water Resources Management: The Seven Mismatches. Int. J. Water Resour. Dev. 2004, 20, 565-575. 
25. Real Decreto Legislativo 1/2001, de 20 de julio, por el que se aprueba el texto refundido de la Ley de Aguas. Available online: http://civil.udg.es/normacivil/estatal/reals/LAguas3.htm (accessed on 24 December 2014). (In Spanish)

26. Plan Hidrológico del Ebro 2010-2015. Available online: http://www.chebro.es/ contenido.visualizar.do?idContenido=14093\&idMenu=3048 (accessed on 24 December 2014). (In Spanish)

27. Plan Hidrológico de la Demarcación (ciclo 2015-2021) y Plan de Gestión del Riesgo de Inundación. Available online: http://www.chsegura.es/export/descargas/planificacionydma/ planificacion15-21/docsdescarga/DIE_PHC_2015-21.pdf (accessed on 24 December 2014). (In Spanish)

28. Atwii, M.; Arrojo, P. Local Government Practices and Experiences in IWRM in the River Basin of the Ebro, Spain; Foundation for a New Water Culture (FNCA): Zaragoza, Spain, 2007.

29. IDE-Ebro: La Infraestructura de Datos Espaciales de la Confederación Hidrográfica del Ebro. Available online: http://iaaa.cps.unizar.es/curriculum/08-Publicaciones-Articulos/art_2009_ Mapping_IDEEbro.pdf (accessed on 24 December 2014). (In Spanish)

30. Milano, M.; Ruelland, D.; Dezetter, A.; Fabre, J.; Ardoin-Bardin, S.; Servat, E. Modeling the current and future capacity of water resources to meet water demands in the Ebro basin. J. Hydrol. 2013, 500, 114-126.

31. Confederación Hidrográfica del Ebro. Ministerio de Medio ambiente y Medio Rural y Marino. Available online: http://www.chebro.es/contenido.visualizar.do?idContenido=3077\&idMenu=2237 (accessed on 29 December 2014). (In Spainish)

32. MMA. Sostenibilidad y Territorio. Huella hídrica de España. Available online: http://www.magrama.gob.es/es/agua/temas/planificacion-hidrologica/libro-blanco-del-agua/ (accessed on 29 December 2014).

33. López-Moreno, J.I.; Morán Tejeda, E.; Revuelto, J.; Gilaberte, M.; Zabalza, J.; Vicente-Serrano, S.M. Water availability and management in the Pyrenees under projected scenarios of climate and land use change. In 1st International Workshop; San Cristobal de La Laguna: Tenerife (Canary Islands), Spain, 2013.

34. García-Vera, M.Á. The application of hydrological planning as a climate change adaptation tool in the Ebro basin. Int. J. Water Resour. Dev. 2012, 29, 219-236.

35. Libro Blanco del Agua en España. Available online: http://www.magrama.gob.es/es/agua/ temas/planificacion-hidrologica/sintesis_tcm7-28955.pdf (accessed on 29 December 2014).

36. Libro digital del agua. Available online: http://servicios2.marm.es/sia/visualizacion/lda/ (accessed on 29 December 2014).

37. Ibañez, C.; Prat, N. The environmental impact of the Spanish national hydrological plan on the lower Ebro river and delta. Int. J. Water Resour. Dev. 2003, 19, 485-500.

38. Prat, N.; Ibañez, C. Effects of water transfers projected in the Spanish National Hydrological Plan on the ecology of the lower River Ebro (N.E. Spain) and its delta. Water Sci. Technol. 1995, $31,79-86$.

39. Chavez-Jimenez, A.; Lama, B.; Garrote, L.; Martin-Carrasco, F.; Sordo-Ward, A.; Mediero, L. Characterisation of the Sensitivity of Water Resources Systems to Climate Change. Water Resour. Manag. 2013, 27, 4237-4258. 
40. Martin-Carrasco, F.; Garrote, L.; Iglesias, A.; Mediero, L. Diagnosing Causes of Water Scarcity in Complex Water Resources Systems and Identifying Risk Management Actions. Water Resour. Manag. 2013, 27, 1693-1705.

41. Corominas Masip, J. La política de regadíos. ¿es sostenible la propuesta del Plan hidrológico del Ebro de incrementar los regadíos en un 50\%? In the Conference Recrecimiento o decrecimiento. Alternativas a Yesa, Navarra, Spain, 28 September 2013. (In Spanish)

42. Anejo X. Programa de Medidas Horizonte 2010-2015. Available online: http://www.chebro.es:81/ Plan\%20Hidrologico\%20Ebro\%202010-2015/Memoria/7.-\%20Anejos/10.-\%20Programa\% 20de\%20medidas/1.\%20ANEJO\%20X\%20y\%20AP\%201.pdf (accessed on 24 December 2014). (In Spanish)

43. Gallart, F.; Llorens, P. Observations on land cover changes and water resources in the headwaters of the Ebro catchment, Iberian Peninsula. Phys. Chem. Earth Parts A/B/C 2004, 29, 769-773.

44. Vicente-Serrano, S.M.; Lasanta, T.; Romo, M. Analysis of spatial and temporal evolution of vegetation cover in the Spanish central Pyrenees: Role of human management. Environ. Manag. 2004, 34, 802-818.

45. López-Moreno, J.I.; Beguería, S.; García-Ruiz, J.M. Trends in high flows in the Central Spanish Pyrenees: response to climatic factors or to land-use change? Hydrol. Sci. 2006, 51, 1039-1050.

46. López-Moreno, J.I.; Beniston, M.; García-Ruiz, J.M. Environmental change and water management in the Pyrenees: Facts and future perspectives for Mediterranean mountains. Glob. Planet. Change 2008, 61, 300-312.

47. López-Moreno, J.I.; Vicente-Serrano, S.M.; Moran-Tejeda, E.; Zabalza, J.; Lorenzo-Lacruz, J.; García-Ruiz, J.M. Impact of climate evolution and land use changes on water yield in the Ebro basin. Hydrol. Earth Syst. Sci. 2010, 7, 2651-2681.

48. López-Moreno, J.I.; Vicente-Serrano, S.M.; Zabalza, J.; Revuelto, J.; Gilaberte, M.; Azorín-Molina, C.; Morán-Tejeda, E.; García-Ruiz, J.M.; Tague, C. Respuesta hidrológica del Pirineo central al cambio ambiental proyectado para el siglo XXI. Pirineos 2014, 169, doi:10.3989/Pirineos.2014.169004. (In Spanish)

49. García-Garizábal, I.; Causapé, J.; Abrahao, R.; Merchan, D. Impact of Climate Change on Mediterranean Irrigation Demand: Historical Dynamics of Climate and Future Projections. Water Resour. Manag. 2014, 28, 1449-1462.

50. Cabrera, E. La Burbuja Hídrica. Levante, 5 February 2011.

51. Water Framework Directive (WFD). 2000/60/EC of the European Parliament and of the Council of 23 October 2000 establishing a framework for Community action in the field of water policy. Off. J. Eur. Communities 2000, 327, 1-73.

52. Assessment on the National Reform Program and Stability Program for Spain for 2012. Available online: http://ec.europa.eu/europe2020/pdf/nd/swd2012_spain_en.pdf (accessed on 24 December 2014).

53. De Stefano, L.; Hernández-Mora, N. Water planning and management after the EU Water Framework Directive. In Water, Agriculture and the Environment in Spain: Can We Square the Circle? Stefano, L.D., Llamas, R., Eds.; CRC Press: Leiden, The Netherlands, 2012. 
54. López-Gunn, E.; Cabrera, E.; Custodio, E.; Huertas, E.; Villarroya, F. Institutional reform in Spain to address water challenges. In Water, Agriculture and the Environment in Spain: Can We Square the Circle? Stefano, L.D., Llamas, R., Eds.; CRC Press: Leiden, The Netherlands, 2012.

55. Pulido-Velazquez, M.; Alvarez-Mendiola, E.; Andreu, J. Design of efficient water pricing policies integrating basinwide resource opportunity costs. J. Water Resour. Plan. Manag. 2013, 139, 583-592.

56. Riegels, N.; Pulido-Velazquez, M.; Doulgeris, C.; Sturm, V.; Jensen, R.; Møller, F.; Bauer-Gottwein, P. A Systems Analysis Approach to the Design of Efficient Water Pricing Policies under the EU Water Framework Directive. J. Water Resour. Plan. Manag. 2013, 139, $574-582$.

57. Maestu, J.; Villar, A. Precios y Costes de los Servicios del Agua en España. Informe Integrado de Recuperación de Costes de los Servicios de Agua en España. Artículo 5 y Anejo III de la Directiva Marco de Agua; Ministerio de Medio Ambiente: Madrid, Spain, 2007. (In Spanish)

58. Bielsa, J.; Cazcarro Castellano, I.; Groot, E.; Sánchez Chóliz, J. Capítulo 14. El coste financiero en la DMA. Tarifas sobre el uso del agua en agricultura. In La economía del Agua de riego en España. Una Perspectiva Regional; Gómez-Limón, J.A., Calatrava, J., Garrido, A., Sáez, F.J., Xabadia, À., Eds.; Fundación Cajamar Caja Rural: Almería, Spain, 2009; pp. 263-277.

59. Real Decreto 849/1986, de 11 de abril, por el que se aprueba el Reglamento del Dominio Público Hidráulico, que desarrolla los títulos preliminar I, IV, V, VI y VII de la Ley 29/1985, de 2 de agosto, de Aguas. Available online: https://www.boe.es/buscar/act.php?id=BOE-A-1986-10638 (accessed on 24 December 2014). (In Spanish)

60. Ley 29/1985 de aguas, de 2 de agosto. Available online: https:/www.boe.es/diario_boe/ txt.php?id=BOE-A-1985-16661 (accessed on 24 December 2014). (In Spanish)

61. Tortajada, C.; Joshi, Y.K. Water resources management and governance as part of an overall framework for growth and development: The case of Singapore. Int. J. Water Gov. 2013, 1, 285-306

62. Blomquist, W.; Schlager, E. Political pitfalls of integrated watershed management. Soc. Nat. Resour. 2005, 18, 101-117.

63. North, D.C. Institutions, Institutional Change and Economic Performance; Cambridge University Press: Cambridge, UK, 1990.

64. North, D.C. Institutional Change: A Framework of Analysis; EconWPA: St. Louis, MO, USA, 1994.

65. Taylor, M.; Singleton, S. The communal resource: Transaction costs and the solution of collective action problems. Polit. Soc. 1993, 21, 195-214.

66. Williamson, O.E. The economics of organization: The transaction cost approach. Am. J. Sociol. 1981, 87, 548-577.

67. Baumgartner, F.; Jones, B.D. Agendas and Instability in American Politics; University of Chicago Press: Chicago, IL, USA, 1993.

68. Sabatier, P.A.; Jenkins-Smith, H.C. Policy Change and Learning: An Advocacy Coalition Approach; Westview Press: Boulder, CO, USA, 1993.

69. Stone, D. Policy Paradox: The Art of Political Decision Making; W.W. Norton: New York, NY, USA, 2002. 
70. Fischhendler, I.; Heikkila, T. Does Integrated Water Resources Management Support Institutional Change? The Case of Water Policy Reform in Israel. Available online: http://www.ecologyandsociety.org/vol15/iss11/art14/ (accessed on 24 December 2014).

71. Kingdom, J.W. Agendas, Alternatives, and Public Policies, 2nd ed.; Harper Collins College Publisher: New York, NY, USA, 1995.

72. Kartin, A. Factors inhibiting structural changes in Israel's water policy. Polit. Geogr. 2000, 19, 97-115.

73. Sánchez-Chóliz, J. Economic Analysis of Water Use. Scheme of Important Issues. Hydrological Plan; Confederación Hidrográfica del Ebro: Zaragoza, Spain, 2007. (In Spanish)

74. Rugge, T. From Small Demonstration Project to Large-Scale Implementation; Corrections Research, Public Safety Canada: Ottawa, ON, Canada, 2013.

75. Bonta, J.; Bourgon, G.; Rugge, T.; Gress, C.; Gutierrez, L. Taking the leap: From pilot project to wide-scale implementation of the Strategic Training Initiative in Community Supervision (STICS). Justice Res. Policy 2013, 15, 17-35.

76. Hartmann, A.; Kharas, H.; Kohl, R.; Linn, J.; Massler, B.; Sourang, C. Scaling up Programs for the Rural Poor: IFAD's Experience, Lessons and Prospects (Phase 2). Available online: http://www.brookings.edu/research/papers/2013/01/ifad-rural-poor-kharas-linn (accessed on 24 December 2014).

77. United Nations Development Programme (UNDP). Scaling Up Local Development Innovations; UNDP: New York, NY, USA, 2011.

78. MSI. Scaling Up —From Vision to Large Scale Change: A Management Framework for Practitioners; Management Systems International, Coffey International: Washington, DC, USA, 2012.

79. Kohl, R. Scaling up in Agriculture, Rural Development, and Nutrition. Addressing Institutional Challenges to Large-Scale Implementation. Available online: http://www.ifpri.org/sites/default/ files/publications/focus19_12.pdf (accessed on 24 December 2014).

80. Bach, H.; Clausen, T.J.; Trang, D.T.; Emerton, L.; Facon, T.; Hofer, T.; Lazarus, K.; Muziol, C.; Noble, A.; Schill, P.; et al. From Local Watershed Management to Integrated River Basin Management at National and Transboundary Levels; Mekong River Commission: Vientiane, Lao PDR, 2011.

81. CPWF. Institutional Practices to Scale Up Watershed Management Research; CGIAR Challenge Program on Water and Food (CPWF): Colombo, Sri Lanka, 2013.

82. Darghouth, S.; Ward, C.; Gambarelli, G.; Styger, E.; Roux, J. Watershed Management Approaches, Policies, and Operations: Lessons for Scaling Up; The World Bank: Washington, DC, USA, 2008.

83. Diallo, A.A. Appraisal and Up-Scaling of Water Conservation and Small-Scale Agriculture Technologies In LCB. Available online: http://www.watergovernance.org/documents/WWW_PDF/ 2009/thursday/K21/LCB_Stockholm.pdf (accessed on 29 December 2014).

84. GEF. Mid-Term Report of the Fiji GEF Pacific IWRM Demonstration Project: "Environmental and Socio-Economic Protection in Fiji: Integrated Flood Risk Management in the Nadi River Basin”. Available online: http://www.pacific-iwrm.org/mid-term-reports/GEF-Pacific-IWRMFiji-Draft-Mid-Term-Report.pdf (accessed on 29 December 2014). 
85. De France, J.; Gordon, B.; Schmoll, O.; Williams, T.; International Water Association (IWA). Think Big, Start Small, Scale Up. A Road Map to Support Country-Level Implementation of Water Safety Plans; World Health Organization (WHO): Geneva, Switzerland, 2010.

86. Loeve, R.; Dong, B.; Molden, D.; Li, Y.H.; Chen, C.D.; Wang, J.Z. Issues of scale in water productivity in the Zhanghe irrigation system: Implications for irrigation in the basin context. Paddy Water Environ. 2004, 2, 227-236.

87. Martin, A.; Reyes, J.; Swanson, K. Scaling Up Payment for Watershed Services Programs in the Upper Neuse River Basin, A Feasibility Analysis and Guidance Framework. Available online: http://dukespace.lib.duke.edu/dspace/bitstream/handle/10161/5362/MP_Final.pdf?sequence=3 (accessed on 24 December 2014).

88. Mukhtarov, F. Integrated Water Resources Management: From International Theory to National Practice; Central European University: Budapest, Hungary, 2007.

89. Stucki, V. Search of Integration. Analyzing the Gap between Theory and Practice of Integrated Water Resources Management with Case Studies from West Africa and International Policy Processes; Aalto University School of Engineering: Espoo, Finland, 2011.

90. Chéné, J.-M. Integrated Water Resources Management: Theory versus Practice. Nat. Resour. Forum 2009, 33, 2-5.

91. Jeffrey, P.; Geare, M. Integrated water resources management: Lost on the road from ambition to realisation? Water Sci. Technol. 2006, 53, 1-8.

92. Söderbaum, P.; Tortajada, C. Perspectives for water management within the context of sustainable development. Water Int. 2011, 36, 812-827.

93. Toonen, T. Resilience in public administration: The work of Elinor and Vincent Ostrom from a public administration perspective. Public Admin. Rev. 2010, 70, 193-202.

94. Homenaje al Diálogo Hidráulico en el Matarraña. Dictamen Sobre el río Matarraña. Available online: http://www.ecodes.org/documentos/Matarrana.pdf (accessed on 24 December 2014). (In Spanish)

95. Brun, A. France's Water Policy: The Interest and Limits of River Contracts. In Globalized Water; Springer: Berlin/Heidelberg, Germany, 2014; pp. 139-147.

96. Tippett, J.; Searle, B.; Pahl-Wostl, C.; Rees, Y. Social learning in public participation in river basin management-Early findings from HarmoniCOP European case studies. Environ. Sci. Policy 2005, 8, 287-299.

97. WSSD. Report of the World Summit on Sustainable Development. In Proceedings of the World Summit on Sustainable Development (WSSD), Johannesburg, South Africa, 26 August-4 September 2002.

98. Font, N.; Subirats, J. Water management in Spain: the role of policy entrepreneurs in shaping change. Available online: http://www.ecologyandsociety.org/vol15/iss2/art25/ (accessed on 24 December 2014).

99. Arrojo, P. El Reto ético de la Nueva Cultura del Agua: Funciones, Valores y Derechos en Juego; Editorial Paidós: Barcelona, Spain, 2006. (In Spainish)

100. Walsh, C. Managing urban Water Demand in neoliberal northern Mexico. Hum. Org. 2011, 70, $54-62$. 
101. Martínez Fernández, J. Challenges for a new water culture in the Mediterranean. In Water Culture and Water Conflict in the Mediterranean Area; Centre International de Hautes Etudes Agronomiques Méditerranéennes (CIHEAM): Hammamet, Tunisia, 2008; pp. 55-68.

102. Bakker, K. From State to Market: Water Mercantilization in Spain. Environ. Plan. A 2002, 34, 767-790.

(C) 2014 by the authors; licensee MDPI, Basel, Switzerland. This article is an open access article distributed under the terms and conditions of the Creative Commons Attribution license (http://creativecommons.org/licenses/by/4.0/). 